\title{
Improving Student Learning Outcomes in Lessons of History of Islamic Civilization Through the Application of Bingo Strategies
}

\author{
Desti Widiani \\ Institut Agama Islam Negeri (IAIN) Surakarta, Indonesia \\ destiwidi@yahoo.com \\ Jiyanto \\ Institut Seni Indonesia Surakarta, Indonesia \\ jiyanto89@yahoo.com
}

\begin{abstract}
This article is a field research using the "Classroom Action Research" method. Learning the History of Islamic Civilization at MTs Muhammadiyah 1 Gemolong in class VII, found several problems, namely the teaching and learning process so far still tended to use the lecture method has not been varied with other methods. This results in student learning outcomes still low. Based on existing conditions, it is necessary to improve the learning process of teaching Islamic Civilization History. Therefore classroom action research is conducted to improve student learning outcomes in the subjects of Islamic Civilization History by applying bingo strategies. The purpose of this study is to improve student learning outcomes in the subjects of Islamic Civilization History and increase student activity in Islamic Civilization History subjects. The action hypothesis in this study is to apply the bingo strategy to improve student learning outcomes and student activities in Islamic Civilization History subjects. Based on the indicators of success of the actions determined from the 3 research cycles, the student learning outcomes reach the classical success limit ( $\geq 85 \%$ ) of all students who have achieved individual success (score $\geq 60$ ) and most students (75\%) actively engage in learning or The teacher has reduced his dominance in learning, showing that student learning outcomes in the subjects of History of Islamic Civilization through the application of bingo strategies can increase. Before the action is carried out the percentage of student success is $21 \%$. In the first cycle student learning outcomes increased to $82 \%$, while in the second cycle the percentage of success was $95 \%$ and in the third cycle the success of students reached 100\%. Student activities on the subject of Islamic Civilization History through the application of increased bingo strategies, before the actions of passive students are carried out in learning activities and the teacher dominates in learning activities. In the first cycle the percentage of student activity was $68 \%$ with the criteria of good / very good, in the second cycle of $95 \%$ and in the third cycle student activity reached $100 \%$. This shows that students are doing well / very well in learning the History of Islamic Civilization and the teacher has been reduced to dominate in learning activities. Thus the bingo strategy can be a solution to improve learning outcomes in Islamic Civilization History subjects.
\end{abstract}

Keywords. Learning Achievement; Activity; Bingo Strategy.

Abstrak. Artikel ini merupakan penelitan lapangan yang menggunakan metode "Classroom Action Research" atau Penelitian Tindakan Kelas (PTK). Pembelajaran Sejarah Kebudayaan Islam di MTs Muhammadiyah 1 Gemolong di kelas VII, menemukan beberapa masalah, yaitu proses belajar mengajar yang selama ini masih cenderung menggunakan metode ceramah belum bervariasi dengan metode lain. Ini mengakibatkan hasil belajar siswa masih rendah. Berdasarkan kondisi yang ada, maka perlu meningkatkan proses belajar mengajar Sejarah Kebudayaan Islam. Oleh karena itu penelitian tindakan kelas dilakukan untuk meningkatkan hasil belajar siswa dalam mata pelajaran Sejarah Kebudayaan Islam dengan menerapkan strategi bingo. Tujuan dari penelitian ini adalah untuk meningkatkan hasil belajar siswa dalam mata pelajaran Sejarah Kebudayaan Islam dan meningkatkan aktivitas siswa dalam mata pelajaran Sejarah Kebudayaan Islam. Hipotesis tindakan dalam penelitian ini adalah menerapkan strategi bingo untuk meningkatkan hasil belajar siswa dan aktivitas siswa dalam mata pelajaran Sejarah Kebudayaan Islam. Berdasarkan indikator 
Desti Widiani, Jiyanto: Improving Student Learning Outcomes ...

keberhasilan tindakan yang ditentukan dari 3 siklus penelitian, hasil belajar siswa mencapai batas keberhasilan klasik ( $\geq 85 \%$ ) dari semua siswa yang telah mencapai keberhasilan individu (skor $\geq$ 60) dan sebagian besar siswa (75\%) aktif terlibat dalam pembelajaran atau Guru telah mengurangi dominasinya dalam belajar, menunjukkan bahwa hasil belajar siswa dalam mata pelajaran Sejarah Kebudayaan Islam melalui penerapan strategi bingo dapat meningkat. Sebelum tindakan dilakukan, persentase keberhasilan siswa adalah 21\%. Pada siklus pertama hasil belajar siswa meningkat menjadi 82\%, sedangkan pada siklus kedua persentase keberhasilan adalah 95\% dan pada siklus ketiga keberhasilan siswa mencapai $100 \%$. Kegiatan siswa pada subjek Sejarah Kebudayaan Islam melalui penerapan strategi bingo meningkat, sebelum tindakan siswa pasif dilakukan dalam kegiatan belajar dan guru mendominasi dalam kegiatan belajar. Pada siklus pertama persentase aktivitas siswa adalah 68\% dengan kriteria baik / sangat baik, pada siklus kedua 95\% dan pada siklus ketiga aktivitas siswa mencapai $100 \%$. Ini menunjukkan bahwa siswa melakukan dengan baik / sangat baik dalam mempelajari Sejarah Kebudayaan Islam dan guru telah berkurang untuk mendominasi dalam kegiatan belajar. Dengan demikian strategi bingo dapat menjadi solusi untuk meningkatkan hasil belajar dalam mata pelajaran Sejarah Kebudayaan Islam.

Kata kunci: Prestasi Belajar; Aktivitas; Strategi Bingo

Copyright (C J-PAI: Jurnal Pendidikan Agama Islam. All Right Reserved.

This is an open access article under the CC BY-SA license

(https://creativecommons.org/licenses/by-sa/4.0/).

Correspondence Address: jpai@uin-malang.ac.id

\section{A. INTRODUCTION}

The standard setting of the education process is a very important and strategic policy for equity and improving the quality of education. Through the standard educational process each teacher can determine how the learning process should take place. The learning process is a series of activities involving various components. So to improve the quality of the learning process can be started from analyzing each component that can shape and influence the learning process. The component which has been considered to have greatly influenced the education process is a component of the teacher. Because after all good and ideal education curriculum, however complete the educational facilities and infrastructure are, without being balanced with the teacher's ability to implement it, then everything will be in vain (Wina Sanjaya, 2006).

For a teacher must have the skills and ability to choose strategies and learning methods that are suitable with the curriculum objectives. This is based on the assumption that the accuracy in choosing a method and using various types of learning strategy models will influence student learning outcomes. Teachers in the teaching and learning process must also be able to utilize learning facilities and infrastructure so that learning objectives can be achieved optimally.

The History of Islamic Culture is one of the subjects of Islamic Education which is directed at preparing students to know, understand, appreciate the History of Islamic Culture, which then becomes the way of life through the activities of guidance, teaching, training, use of experience and habituation (National Education Standards Agency, 2007). Thus learning History of Islamic Culture is not only by listening to what is described by the teacher of Islamic Civilization History subjects but students through activities of guidance, training and habituation in learning activities.

This is in line with the content standards of Madrasah Tsanawiyah issued by the Ministry of Religion of the Republic of Indonesia (MoRA, 2016), that the material taught at the Madrasah Tsanawiyah level for Islamic Civilization History subjects includes: History of the Umayyad Dynasty, History of the Abbasid Dynasty and History of the Ayubiyah, with emphasis on the ability to explore values, meanings, axioms of ibrah / wisdom, theorems and theories of existing historical facts. So History of Islamic Culture is not only a transfer of knowledge, but also a value education. 
In learning the History of Islamic Culture found several weaknesses as mentioned in the National Education Standards Agency, among others: limited time but the material is so dense and indeed important, material History of Islamic Culture is more focused on enriching knowledge (cognitive) and minimal in the formation of attitudes (affective ), the lack of participation of other subject teachers in giving motivation to students to practice the values of the History of Islamic Culture in daily life, and the weakness of teacher resources in developing more varied approaches and methods, and the lack of training and development facilities (National Education Standards Agency, 2007).

To achieve what is expected in the National Education Standards Agency and the Content Standards there are still many problems faced by both teachers and students. Among them are the lack of teachers' ability to develop a learning atmosphere that supports students to learn and the development of approaches and learning methods that have not varied, for example with a game in teaching and learning activities. This condition results in student learning outcomes still low, this is evidenced by the results of the Semester Midwifery which amounted to 38 students, as many as 30 or about $79 \%$ have not succeeded in getting a score of 60 as the success limit.

Based on the background above, the problem can be formulated as follows: (1) can applying the bingo strategy improve student learning outcomes in Islamic Civilization History subjects? and (2) can applying bingo strategies increase student activity in Islamic Civilization History subjects?

This study aims to: (1) to improve student learning outcomes in the subjects of Islamic Civilization History by applying bingo strategies, and (2) to increase student activity in Islamic Civilization History subjects by applying bingo strategies.

\section{B. RESEARCH METHODS}

\section{Research Design}

This study aims to solve problems that arise in the world of work of researchers with regard to the low learning outcomes of History of Islamic Culture as a result of low student activity, learning which is still dominated by teachers. By giving a class action because of that the method used in this study is the "Classroom Action Research" method. In its implementation it involves a collaborative team.

In carrying out this research there are four stages that are passed namely Planning, Implementation, Observation and Reflection. The implementation of each cycle is based on input from the previous cycle (Suharsimi Arikunto, 2006). The procedure of this study consists of three cycles, each cycle in this class action research includes activities.

\section{Picture 1.}

Stage of Implementation of Class Action Research in 3 Cycles

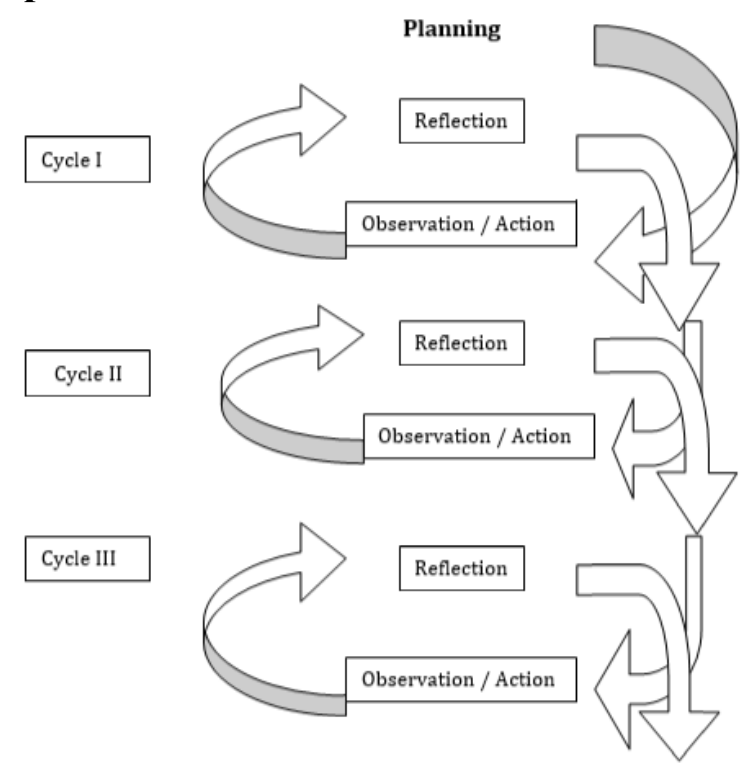


Desti Widiani, Jiyanto: Improving Student Learning Outcomes ...

The steps above constitute a unity in the cycle, in the study the cycle of action always repeats itself. After one cycle is complete, maybe the teacher will find new problems or old problems that have not been solved, followed by the second cycle and so on as in the first cycle (Mundilarto, 2004).

This class action research was designed into 3 cycles, each of which in the cycle includes the activities as described above, namely planning, implementing, observing and reflecting.

\section{Research sites and participants}

The study was conducted at MTs Muhammadiyah 1 Gemolong, Sragen, Central Java. The time used for research began on February 5 to April 30, 2017. The subjects of this study were students of class VII A MTs Muhammadiyah 1 Gemolong 2017/2018 school year. With a total of 38 students with details of 19 male students and 19 female students.

\section{Data collection and analysis}

Data collection techniques using tests of student learning outcomes in the subjects of Islamic Civilization History at the end of the cycle, student activity observation sheets. In this study the researcher used participant observation, namely the researcher was directly involved in the process of learning activities as a teacher practicing Islamic Civilization History subjects and cooperating with Islamic Civilization History subject teachers and VII A homeroom teacher, questionnaire sheets at the end of the third cycle, and documentation. Researchers use this documentation because often the more valid meaning is obtained, which is to find data on things in the form of notes, transcripts, books, newspapers, magazines and so on (Suharsimi Arikunto, 2006). This method the writer uses to get recapitulation data about attendance attendance, list of values, student achievement and student activities in the form of photos during learning activities.

Data analysis was performed to answer the hypothesis, namely by implementing a bingo strategy can improve student learning outcomes and student activities. The data analysis technique in this study uses descriptive statistics. Descriptive statistics according to Sugiyono (2006) are statistics used to analyze data by describing or describing collected data as they are. Descriptive statistics to process the characteristics of the data related to adding, on average, looking for the midpoint, looking for percentages and presenting interesting, easy to read data, and followed by the flow of thinking such as graphs and tables (Suharsimi Arikunto, 2006).

The steps carried out in data analysis are by grouping data, tabulating data, presenting data for each variable under study and performing calculations to answer the problem statement. The analysis technique used is to calculate the percentage of value acquisition and value increase in each cycle.

\section{RESULTS AND DISCUSSION}

\section{Theoretical Framework}

\section{a. Bingo Learning Strategies}

According to the Encyclopedia of Education in Gulo (2002) strategy is "the art of bringing forces to the battle field in favorite position" namely the art that brings troops on the battlefield in the most advantageous position. While the learning strategy according to J.R. David in Wina Sanjaya (2006) says as follows: "a plan, method, or series of activities designed to achieve a particular educational goal" according to this understanding the strategy includes plans, methods, and sets of activities planned to achieve teaching goals. Thus the learning strategy is a series of activities (including plans, methods, use of various devices) that will be used by the instructor to achieve certain goals so that it is easier for students to receive and understand the subject matter, which ultimately can be achieved optimally. 
This research emphasizes on improving student learning outcomes by implementing a bingo strategy developed by Silberman. (Silberman, 2006) Bingo strategy is one of the active learning strategies centered on students, in the implementation of the teacher as a guide and facilitator for students. The bingo strategy was first coined by Melvin L. Silberman, a Professor of Educational Psychology Studies at Temple University. He has an internal reputation in the active learning process. The strategy applied is in the form of bingo card games. In this case the bingo card is a learning strategy. The bingo card that is used as a learning strategy is a card that is made by the teacher himself which contains questions about the material of Islamic Civilization History to be studied.

\section{b. Types of Learning Strategies}

There are several learning strategies that can be used. Rowntree stated in Wina Sanjaya (2006) that there are three types of learning strategies when viewed from message processing or material activities, namely:

1) Exposition-Discovery Learning

Strategy In the expository strategy the teacher is only as an informant, but in discovery strategies, learning material is sought and found by students through various activities, the teacher is only a facilitator and mentor.

2) Individual Learning Strategy

The application of this strategy is done independently by students through modules, or through audio tapes.

3) Group Learning Strategy

The group learning strategy is carried out in groups, both large groups or small groups.

Thus the group learning strategy will create a mutually beneficial learning atmosphere among students. Students who are classified as having more ability will be able to help their friends who have deficiencies in understanding the subject matter. The teacher before determining the learning strategy that will be applied needs to look at the subject matter first whether it will be delivered individually, groups or students do various kinds of activities to find answers to the problems faced by these students.

Based on the components that are under pressure in the teaching process, the types of learning strategies can be grouped into three types of learning strategies as Gulo (2002) which say: "Teacher-centered teaching and learning strategies, learner-centered teaching and learning strategies, learning strategies teaching centered on teaching material ".

Each of these components, namely teachers, students and teaching materials gets a more portion in teaching and learning activities depending on the type of strategy applied by the teacher. At present the strategy that gets pressure in the learning process is a strategy that is centered on students, because students will do various kinds of learning activities.

Whereas when viewed from the way of processing or processing messages or material, it is divided into two types:

1) Deduction teaching and learning strategies, namely messages processed from general to specific, from abstract things to concrete things, from abstract concepts to concrete examples.

2) Induction teaching and learning strategies, namely processing messages that start from things that are specific to general things, from individual events to generalizations, from individual empirical experiences to general concepts (Gulo, 2002).

In learning activities if the method of processing messages or material is deduction, the teacher will reveal the material globally or whole and then the students will be given 
Desti Widiani, Jiyanto: Improving Student Learning Outcomes ...

examples or events that can be found around it. Conversely, if the teacher implements a teaching strategy that induction the teacher will describe the subject matter in the form of events or previous examples of the material, then the teacher will convey the concepts in general.

\section{c. Components of Learning Strategies}

Dick and Carey in Hamzah B. Uno (2007) mention that there are five components of learning strategies, namely: (1) Preliminary learning activities include explaining the indicators to be achieved, performing apperception, (2) Submitting information about the scope of material and material will be delivered, (3) Participation of students because students are learning centers, (4) Tests, (5) Follow-up activities namely students receive follow-up from the learning outcomes.

The subject matter in general is a combination of types of material in the form of knowledge (facts and detailed information), skills and attitudes (containing opinions, ideas, suggestions, or responses). Subject matter can be classified into four categories, namely facts, procedures, concepts and principles. In the contents of this lesson, it appears that each type of lesson definitely requires different delivery strategies. Therefore, in determining the learning strategy, the teacher must first understand the type of subject matter to be delivered in order to obtain the appropriate learning strategy.

Furthermore Gulo (2002) revealed that the components of the learning strategy consisted of seven components namely teaching objectives, teachers, students, subject matter, teaching methods, teaching media as well as financial and administrative factors, included in this component are lesson schedules, building conditions and study room.

The condition of each input component in the learning strategy is different for each educational institution. Therefore, if you want to achieve a predetermined competency standard you should consider the components of the learning strategy.

There are several considerations in the selection of learning strategies as explained by Sanjaya (2006) consisting of: (1) considerations related to the goals to be achieved, (2) considerations relating to learning materials or materials (learning material can be factual, certain concepts, laws or theories), (3) considerations from the students 'point of view, namely from the students' maturity, interests, talents and conditions of students and student learning styles.

Thus before the teacher determines what strategies will be applied in the teaching and learning process, it must consider the objectives, learning material and from the students themselves according to their interests and learning styles. Based on a number of considerations above, the main objective is for the strategy to be implemented effectively and efficiently, it requires the creativity of the teacher in choosing the learning strategy. Because taking into account the various kinds of things mentioned above, maximum learning outcomes will be achieved.

\section{d. Student Learning Outcomes}

Learning outcomes are abilities possessed by students after he receives his learning experience. Bloom in Nana Sudjana (1995) classifies learning outcomes into three domains, namely:

1) The cognitive domain is related to intellectual learning outcomes which consist of six aspects, namely knowledge or memory, understanding, application, analysis, synthesis and evaluation.

2) The affective domain deals with attitudes which consist of five aspects, namely acceptance, answer or reaction, assessment, organization and internalization.

3) The psychomotor domain is concerned with the results of learning skills and the ability to act. 
The objective domain of the assessment is behavior, not students 'knowledge, so the answer does not have to be right or wrong because it only measures students' attitudes and interests. Whereas in the psychomotor domain the measurement is put together or begins with the measurement of the cognitive domain first because the assessment is aimed at learning outcomes in the form of students' skills.

\section{e. Student Activities in Islamic Civilization History}

SubjectsIn the learning process the role of the teacher is to guide and facilitate students in gaining their learning experience. Thomas M. Risk in Daradjat et al. (Zakiyah Daradjat, 2004) says the following: "teaching is the guidance of learning expe- rience", teaching is a guiding process, learning experience.

This experience can be achieved by students if students are active in their learning environment. The teacher can help students learn, but the teacher cannot learn for the child. If a student wants to learn to solve a problem, he must think according to certain steps; if he wants to master a skill, he must practice coordinating certain muscles, and if he wants to have certain attitudes, he must have some emotional experience. Teaching and learning activities are needed activities, because in principle learning is doing, doing to change behavior, so doing activities, no learning if there is no activity.

Montessori in Sardiman (2001) also emphasizes that children have the power to develop themselves, form themselves. Educators will take on the role of mentors and observe the development of their students. This shows that those who do more activities in the formation of themselves are the children themselves, while educators provide guidance and plan all activities that will be carried out by students.

Furthermore Piaget explained that a child thinks as long as he does. Without action, children do not think. In order for children to think for themselves, they must be given the opportunity to do it themselves. Thinking on a new verbal level arises after the child thinks at the level of action. So thus the activities carried out by students in the learning process include activities physically and spiritually (Nasution, 1995).

Many kinds of activities that can be carried out by children in teaching and learning activities in schools, students do not only record and listen but can engage in activities both physically (reading, asking, paying attention, drawing opinions, discussing) psychological/mental activities (solving problems, responding, remembering, etc.).

Student activities in learning activities are divided into various types, namely as follows (Nasution, 1995):

1) Visual activities, such as reading, paying attention: pictures, demonstrations, experiments, other people's work and so on

2) Oral activities, such as expressing, formulating, asking, giving advice, issuing opinions, holding, interviews, discussions, interruptions, and so on

3) Listening activities, such as listening to descriptions, conversations, discussions, music, speeches and so on

4) Writing activities, such as writing stories, essays, reports, tests, questionnaires, copying and so on.

5) Drawing activities, such as drawing, making graphics, maps, diagrams, patterns and so on.

6) Motor activities, such as conducting experiments, making construction, modeling, repairing, playing, gardening, raising animals, and so on.

7) Mental activities, such as responding, remembering, solving problems, analyzing, seeing relationships, making decisions and so on.

8) Emotional activities, such as taking interest, feeling bored, happy, brave, calm, nervous and so on. 
Desti Widiani, Jiyanto: Improving Student Learning Outcomes ...

The classification of forms of active learning activities is also stated in Hamalik (2003), namely investigation activities, presentation activities, training activities, appreciation, observation and listening activities, creative, working in groups, experiments and organizing and judging activities.

The activities in the learning process mentioned above are not separated one by one, but these activities support each other between each other because in each motor activity mental activities are contained and accompanied by certain feelings. These student activities are principles or principles that are very important in teaching and learning interaction.

\section{Findings And Discussion}

Material in the bingo strategy applied to grade VII students is the biography of Caliph Umar bin Abdul Aziz, the efforts and services of Caliph Umar bin Abdul Aziz and the example of Caliph Umar bin Abdul Aziz and the biography of Caliph Hisham bin Abdul Malik, efforts and services - the service of Caliph Hisham bin Abdul Malik as well as the wisdom of Caliph Caliph Hisham bin Abdul Malik.

\section{Cycle I}

Stages in cycle I:

\section{a. Planning}

In the first cycle learning activities begin with the making of a learning plan. The material presented is the biography of the Caliph Umar bin Abdul Aziz and the efforts made by the Caliph Umar bin Abdul Aziz. The material to be studied has been presented on bingo cards.

\section{b. Implementation}

The teacher first examines the readiness of students, checking student attendance and conditioning the classroom so that learning can take place conducive. Then apperception with questions and answers about the material to be conveyed and an introduction to the bingo strategy that will be applied. The teacher explains the procedure of implementing bingo cards so students can win the bingo game. Then each student is given a bingo card, which the teacher has prepared beforehand. Each bingo card contains questions about material that will be delivered. The teacher gives guidance to students so that students can complete bingo cards correctly. After the allotted time runs out students collect bingo cards. Next the teacher clarifies the results of the answers from students. Then with the guidance of the teacher for students who succeed in answering bingo cards to present their bingo cards in front of the class. Students with teacher guidance concludes the material that has been learned. The teacher closes the lesson and rewards bingo card winners. At the end of the first cycle an evaluation of learning outcomes was carried out which included 20 multiple choice questions.

\section{c. Observation}

Observation of learning activities carried out during the learning process takes place using observation sheets, namely student activity sheets. In this case, researchers aside from acting as teachers as well as observers. In addition, researchers were also assisted by Islamic Civilization History subject teachers and class VII guardians.

Students still find it difficult to be able to complete the bingo card because the subject matter contained in the bingo card in the form of questions is too long so there is not enough time to be able to complete the bingo card.

However, during the learning activities most of the students showed quite enthusiastic responses with a feeling of excitement with enthusiasm emanating from their faces, so they happily attended Islamic Civilization History lessons. Then a student presented a bingo card by recounting the biography and efforts of the Caliph Umar bin Abdul Aziz and the other students listened then continued with question and answer for 
students who still did not understand the biography and efforts of Caliph Umar bin Abdul Aziz.

Student learning outcomes in cycle I in full can be seen in the following table.

Table 1.

Student Learning Outcomes in Cycle I

\begin{tabular}{|c|c|c|c|c|c|}
\hline SOURCE & SCOR & \multicolumn{2}{|c|}{ LEARNING OUTCOMES } & \multirow{2}{*}{ TOTAL } & $\%$ \\
\hline Data & Maximum & Succeeded & $\begin{array}{c}\text { Has not } \\
\text { succeeded }\end{array}$ & & (Classical) \\
\hline Cycle Test I & 20 & 31 & 7 & 38 & 82 \\
\hline
\end{tabular}
follows.

While the results of student activities in the first cycle can be classified in the table as

Table 2.

Classification of Student Activities in Cycle I

\begin{tabular}{clcc}
\hline NO. & \multicolumn{1}{c}{ CRITERIA } & TOTAL & PERCENTAGE \\
\hline 1 & Very Less & 0 & 0 \\
2 & Less & 12 & $32 \%$ \\
3 & Good & 15 & $39 \%$ \\
4 & Very Good & 11 & $29 \%$ \\
\hline
\end{tabular}

\section{d. Reflection}

In the first cycle, which is about biography and the efforts of Caliph Umar bin Abdul Aziz the implementation was carried out in $3 \times$ meetings with an allocation of time of $6 \mathrm{x}$ 40 minutes. The overall implementation of the activity went smoothly, ladies and gentlemen of the observer observers who had to write the names of students who were observed in a short amount of time, and students still felt difficulties so that the students took too long to complete the bingo card.

Student activities in learning have not reached the set success standard of $75 \%$ of student activities in the good / very good category. This is possible because the application of the bingo strategy is still new for students. In the learning process students' interest to ask questions is still low and still embarrassed to appear in front of the class.

For the next meeting students are given homework assignments to summarize the subject matter to be studied so that it can more easily understand the subject matter and be able to complete bingo cards and students are given motivation to prepare the next subject matter.

\section{Cycle II}

\section{a. Planning}

Learning activities in cycle II begin by making a learning plan and correcting weaknesses based on the results of the reflection contained in cycle I. In order to be precise and quick in completing bingo cards each student is given the task to summarize the material to be studied at the next meeting of various related reference books with material on Islamic Civilization History. The subject material in the form of questions is concise but covers the entire subject matter.

Meanwhile, to facilitate observation in observing and evaluating, the observation sheet format includes the name of the student.

\section{b. Implementation}

The activities in the second cycle are carried out the same as in the first cycle, the difference is that at the end of each lesson the students are given a task at home to summarize the learning material that will be studied next and the learning process 
Desti Widiani, Jiyanto: Improving Student Learning Outcomes ...

process is carried out $2 \times$ meetings with a time allocation of $4 \times 40$ minutes. The material of the second cycle is merit and imitating the piety and inhumanity of the Caliph Umar bin Abdul Aziz.

At the end of the second cycle an evaluation of learning outcomes totaling 20 multiple choice questions was carried out.

\section{c. Observation}

Observation of learning activities carried out during the learning process takes place using observation sheets, namely student activity sheets. Researchers in the second cycle were also assisted by Islamic Civilization History teachers and class VII guardians.

When the bingo cards are distributed, students are increasingly curious to successfully complete the bingo card, this is evident from the behavior of those who want to immediately find out the question material contained in the bingo card. Students are mostly accustomed to implementing bingo strategies, their enthusiasm is increasing and there is no difficulty in completing bingo cards so the number of students who successfully complete bingo cards has increased.

In this second cycle students with confidence and are not shy anymore to appear in front of their friends to present their bingo cards.

Table 3.

Student Learning Outcomes in Cycle II

\begin{tabular}{llll|l|c}
\hline SOURCE & SCOR & \multicolumn{2}{|c|}{ LEARNING OUTCOMES } & \multirow{2}{*}{$\begin{array}{c}\% \\
\text { SUCCEEDED }\end{array}$} \\
\cline { 1 - 4 } & Maximum & Succeeded & $\begin{array}{c}\text { Has not } \\
\text { succeeded }\end{array}$ & TOTAL & (Classical) \\
\hline Cycle Test II & 20 & 36 & 2 & 38 & 95 \\
\hline
\end{tabular}

Table 4.

Classification of Student Activities in Cycle II

\begin{tabular}{clcc}
\hline NUMBER & CRITERIA & TOTAL & PERCENTAGE \\
\hline 1 & Very Less & 0 & 0 \\
2 & Less & 2 & $5 \%$ \\
3 & Good & 17 & $45 \%$ \\
4 & Very Good & 19 & $50 \%$ \\
\hline
\end{tabular}

\section{d. Reflection}

In the second cycle which is about services and imitating the piety of the Caliph Umar bin Abdul Aziz the implementation is carried out in $2 \mathrm{x}$ meetings with time allocation of $4 \mathrm{x}$ 40 minutes. The overall implementation of the activity went smoothly, ladies and gentlemen, the observers who conducted direct observations could observe the activities of students without having to write the names of students because the names of students had been written before.

Student learning outcomes have exceeded the research indicators with the number of students who managed to reach 36 students or 95\%. Student activities in learning have reached the standard of success that is equal to $95 \%$ of students already included in the category of good / very good activities. Students are getting excited to be able to complete the questions on the bingo card. In the learning process students' interest to ask the teacher is good and students have begun to dare to appear in front of the class.

The subject matter delivered in the form of questions on bingo cards is made even more interesting in the form of varied boxes so that students are not bored and are even more enthusiastic in learning activities. Students are given homework to make a summary of the whole subject matter that has been studied in order to better understand the subject matter of Islamic Civilization History. 


\section{Cycle III}

\section{a. Planning}

Learning activities in the third cycle begins with making a learning plan and fixing the weaknesses based on the results of the reflection contained in the second cycle. To make students more enthusiastic about implementing bingo cards, the boxes in the bingo cards are made more varied and the bingo cards are made with colorful cartons.

\section{b. Implementation}

The activities in cycle III are carried out the same as in cycle II, the difference is that at the end of each lesson students are given a task at home to summarize the entire learning material that has been and will be studied further and the learning process process is carried out $3 \times$ meetings. The material in this third cycle is Biography, efforts, services and wisdom of the Caliphate Hisham bin Abdul Malik.

After the third cycle ends, an evaluation of learning outcomes totaling 20 multiple choice questions is carried out. To find out the students' final responses to the bingo strategy on learning Islamic Cultural History students were given a questionnaire on their responses to the bingo strategy.

\section{c. Observation}

In this third cycle observations of learning activities are also carried out during the learning process and the observation sheet is the student activity sheet. Researchers in this third cycle are still assisted by Islamic Cultural History subject teachers and class VII guardians.

When the bingo cards are distributed, students are increasingly impatient to be able to successfully complete the bingo card, this is evident from their enthusiasm, attention and enthusiasm. Students are getting used to, their enthusiasm is increasing and there are no difficulties with implementing bingo strategies. In this third cycle, many students pointed their fingers so that they could appear in front of the class to present their bingo cards.

Furthermore, in the third cycle student learning outcomes achieve $100 \%$ success can be seen in the table below.

Table 5.

Student Learning Outcomes in Cycle III

\begin{tabular}{lccccc}
\hline SOURCE & SCOR & \multicolumn{2}{c}{ LEARNING OUTCOMES } & & $\begin{array}{c}\% \\
\text { SUCCEEDED }\end{array}$ \\
\cline { 1 - 4 } Data & Maximum & Succeeded & $\begin{array}{c}\text { Has not } \\
\text { succeeded }\end{array}$ & TOTAL & (Classical) \\
\hline Cycle Test III & 20 & 38 & 0 & 38 & 100 \\
\hline
\end{tabular}

Activities in learning activities can be seen in the following table.

Table 6.

Classification of Student Activities in Cycle III

\begin{tabular}{clcc}
\hline NUMBER & CRITERIA & TOTAL & PERCENTAGE \\
\hline 1 & Very Less & 0 & 0 \\
2 & Less & 0 & $0 \%$ \\
3 & Good & 14 & $37 \%$ \\
4 & Very Good & 24 & $63 \%$ \\
\hline
\end{tabular}

The passive learning process or students only listen from the teacher, have a tendency to quickly forget what has been given. Then certain devices are needed to be able to tie the information that has been given by the teacher, one of them is active 
Desti Widiani, Jiyanto: Improving Student Learning Outcomes ...

learning. Active learning is one way to bind that information and store it in the brain. Because students if they only listen have a number of weaknesses, even though the learning outcomes must be stored for a long time. This condition is in harmony with what was revealed by Confucius, a famous philosopher believes that what I heard, I forgot, what I saw, I remember, what I did I understood.

With the strategy of bingo students in learning activities feel happy, not saturated in learning. The enthusiasm for learning is increasing because every meeting of students is increasingly active in reading textbooks, learning together, answering questions, asking the teacher if it is not clear, working on assignments and so on. The activeness of students in learning results in increased student learning outcomes.

It was proven that before the action was carried out the percentage of student success was $21 \%$ (8 students). Furthermore, student learning outcomes in cycle I to cycle III had an increase in the number of students who got a value of $\geq 60$ with details in the first cycle of the number $\geq 60$ with a class average of 63.81 the percentage of success reached $82 \%$, then in cycle II there were 36 students with a class average of 68.42 the percentage of student success was 95\%, then in cycle III there were 38 students with a class average of 74 or student success reaches $100 \%$.

To more clearly see the improvement in student learning outcomes can be seen in table 7. below.

Table 7.

Increased Student Learning Outcomes in Cycles I, II, and III

\begin{tabular}{lccc}
\hline \multicolumn{1}{c}{ INFORMATION } & CYCLE I & CYCLE II & CYCLE III \\
\hline Successful Students & 31 & 36 & 38 \\
\hline Unsuccessful Students & 7 & 2 & 0 \\
\hline Average & 26 & 29 & 30.15 \\
\hline Percentage of success & 82 & 95 & 100
\end{tabular}

Improving student learning outcomes in cycles I, II, and III can be described as follows.

Figure 1.

Improved Student Learning Outcomes Diagram in Cycles I, II, and III

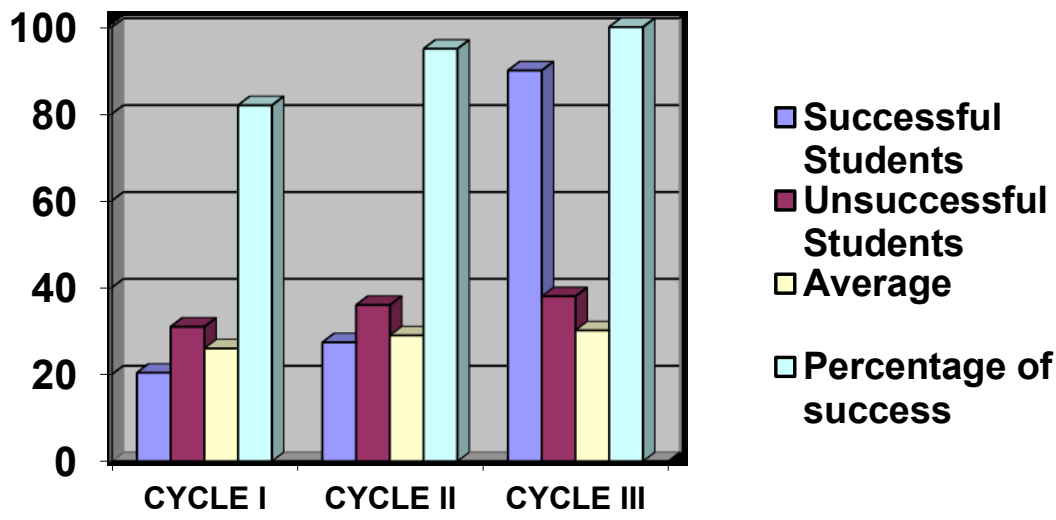

The activity of class VII students from cycle I to cycle III is high, has increased from the average activity of students from 26 in cycle I and student activity 68\%, then on average in cycle II reaches 29 with a percentage of activity 95\%. This means that it has exceeded the established research indicators. Whereas in the third cycle the class average reaches 30.15 with the percentage of student activity at $100 \%$. 
The results of increasing student activity in cycles I, II, and III can be seen in table 8 . below.

Table 8.

Increased Activity of Students in Cycles I, II, and III

\begin{tabular}{llll}
\hline \multicolumn{1}{c}{ INFORMATION } & \multicolumn{1}{c}{ CYCLE I } & CYCLE II & CYCLE III \\
\hline Very Less & 0 & 0 & 0 \\
\hline Less & 12 & 2 & 0 \\
\hline Good & 15 & 17 & 14 \\
\hline Very Good & 11 & 19 & 24 \\
\hline Average & 26 & 29 & 30.15 \\
\hline Percentage of Activity & 68 & 95 & 100 \\
\hline
\end{tabular}

The increase in activity from cycles I, II, and III can be described as follows.

Figure 2.

Student Activity Improvement Diagram of Cycles I, II, and III

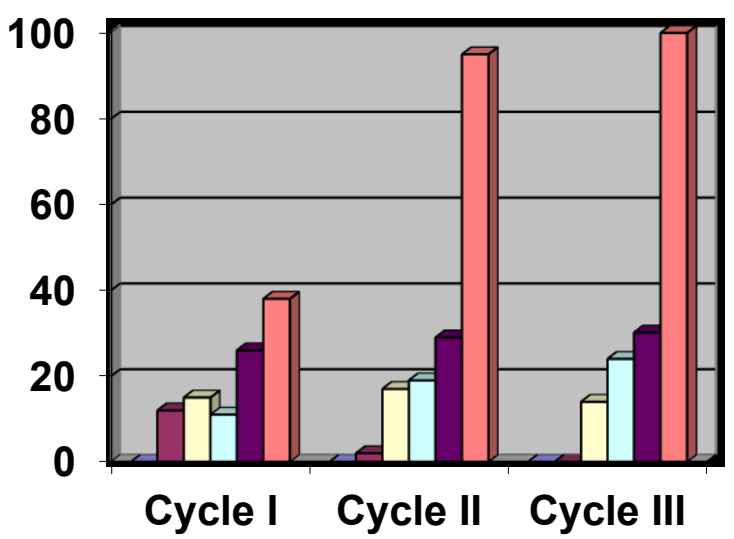

$\square$ Very Less

口Less

口Good

$\square$ Very Good

average

$\square$ Percentage of Activity

Fun student activities, enthusiastic in learning, enthusiastic in the learning process, answering questions from various references, understanding the subject matter students can save it for a long time, so that learning outcomes can be improved.

While the percentage of the results of the questionnaire students' responses to the bingo strategy can be categorized as high, which is around $80 \%$ to $97 \%$ of students agree to strongly agree and often to always apply bingo strategies in Islamic Civilization History subjects.

The results of this research in class action show that by applying the bingo strategy can increase student activity and student learning outcomes in Islamic Civilization History subjects of class VII A MTs Muhammadiyah 1 Gemolong. Students during the learning process feel pleasant, their learning enthusiasm increases, can better understand the subject matter, this is supported by the results of the questionnaire responses of students on Islamic Civilization History subjects.

\section{CONCLUSION}

From the research that the authors did it can be concluded as follows: (1) bingo strategies can improve student learning outcomes in Islamic Civilization History subjects, (2) bingo strategies can increase student activity in Islamic Civilization History subjects.

Islamic Civilization History subject teachers should apply the bingo strategy, because by applying the bingo strategy can improve student learning outcomes. The bingo strategy is expected to be an alternative to learning Islamic Civilization History. There needs to be support and encouragement from the school to teachers who have the spirit of learning innovation in an effort to improve the quality of educational outcomes. 
Desti Widiani, Jiyanto: Improving Student Learning Outcomes ...

\section{REFERENCES}

Arikunto, Suharsimi, Suhardjono \& Supardi, (2006). Penelitian Tindakan Kelas, Jakarta: Bumi Aksara.

Rineka Cipta.

(2002). Prosedur Penelitian Suatu Pendekatan Praktek, Yogyakarta: (2003). Dasar-dasar Evaluasi Pendidikan, Jakarta: PT Bumi Aksara.

Badan Standar Nasional Pendidikan, (2007). Kurikulum Tingkat Satuan Pendidikan Khusus Madrasah Tsanawiyah (MTs), Jakarta: PT Binatama Raya.

Daradjat, Zakiah dkk., (2004). Metodik Khusus Pengajaran Agama Islam, Jakarta: Bumi Aksara.

Darwis, Djamaluddin, (1998). Strategi Belajar Mengajar, dalam Toha, Mu'ti, PBM-PAI di Sekolah Eksistensi dan Proses Belajar Mengajar Pendidikan Agama Islam, Semarang: Fakultas Tarbiyah IAIN Walisongo.

Departemen Agama RI, (2006), Standar Isi Madrasah Tsanawiyah, Jakarta: Direktorat Jenderal Kelembagaan Agama Islam.

Gulo W., (2002). Strategi Belajar Mengajar, Jakarta: PT Gramedia.

Hamalik, Oemar, (2003). Pendekatan Baru Strategi Belajar Mengajar Berdasarkan CBSA, Bandung: Sinar Baru Algesindo.

Majid, Abdul dan Andayani, (2004). Pendidikan Agama Islam Berbasis Kompetensi, Bandung: Rosda Karya.

Mudjijo, (1995). Tes Hasil Belajar, Jakarta: Bumi Aksara.

Nasution, (1995). Didaktik Asas-asas Mengajar, Jakarta: Bumi Aksara.

Rusyan, A., Thabrani, (1992). Strategi Belajar Mengajar, Jakarta: Pustaka Pelajar.

Sanjaya, Wina, (2006). Strategi Pembelajaran Berorientasi Standar Proses Pendidikan, Jakarta: Kencana.

Sardiman, (2001). Interaksi dan Motivasi Belajar Mengajar, Jakarta: PT RajaGrafindo Persada.

Silberman, Melvin L., (1996). Active Learning: 101 Strategi Pembelajaran Aktif, Penerjemah: Raisul Muttaqien, Bandung: Nusamedia.

Sriyono, (1992), Teknik Belajar Mengajar dalam CBSA, Jakarta: Rineka Cipta.

Sudijono, Anas, (2006), Pengantar Evaluasi Pendidikan, Jakarta: PT RajaGrafindo Persada.

Sudjana, Nana, (1995), Dasar-dasar Proses Belajar Mengajar, Bandung: Sinar Baru Algesindo.

Rosdakarya.

(1995), Penilaian Hasil Proses Belajar Mengajar, Bandung: Remaja

Sudjana S., Djudju, (2000), Metode dan Teknik Pembelajaran Partisipatif, Bandung: Falah Production.

Sugiyono, (2006), Metode Penelitian Kuantitatif Kualitatif dan $R \& D$, Cet. II, Bandung: Alfabeta.

Surapranata, Sumarna, (2004), Analisis Validitas Reliabilitas dan Interpretasi Hasil Tes, Bandung: Remaja Rosdakarya.

Syah, Muhibbin, (1999). Psikologi Belajar, Jakarta: Logos Wacana Ilmu.

Thoha, Chabib, (1994). Teknik Evaluasi Pendidikan, Jakarta: PT RajaGrafindo Persada.

Uno, Hamzah B., (2007). Model Pembelajaran Menciptakan Proses Belajar yang Kreatif dan Efektif, Jakarta: Bumi Aksara.

Zaini, Hisyam dkk., (2007). Strategi Pembelajaran Aktif, Yogyakarta: CTSD (Center for Teaching Staff Development) IAIN Sunan Kalijaga. 